\title{
INHIBITORY ACTION OF FUNGICIDES ON GERMINATION OF FUNGAL SPORES OF CERCOSPORA BETICOLA SACC. AND ALTERNARIA ALTERNATA KEISSL.
}

\author{
O. S. Vlasiuk \\ Khmelnitskiy State Agricultural Experimental Station, Institute of feed research and agriculture of \\ Podillia of NAAS \\ 1, Samchyky Str., Samchyky village, Starokostiantynivskyi district, Khmelnytsk region, 31182, \\ Ukraine; vchsekretar-hdsgds@yandex.ru
}

In recent years a clear trend towards strengthening of cercosporosis and Alternaria spot disease of sugar beets has been observed, which affects the yield of crops and the quality of a raw product for the production of sugar $[1 ; 2]$. Despite the significant amount of research, there are substantial differences in the evaluation of the effectiveness of fungicides against these diseases. Almost unexplored is sugar beets blight, which had not been identified before 2000 in our country.

Cercospora beticola Sacc. fungus belongs to necrotrophs - pathogens of spot necroses and is considered highly pathogenic [3]. The prevalence of the disease and often epiphytoty are caused by great potential of $C$. beticola fungus reproduction. Thus, the number of conidia per plant with strong development of spot disease varies from 200 to $500 \mathrm{mln}$. units [4]. It should be noted that cercosporosis is one of the most harmful diseases of sugar beet. Even at low lesions (less than 1 point) the loss of sugar is 5 to $10 \%$, at average (1.5-2 points) - from 20 to $30 \%$, and at strong (over 2 points) - from 30 to $70 \%$ [5]. At this, there are no immune to cercosporosis varieties or hybrids of sugar beet (both among feeding and table beets) [6]. Alternaria alternata (Fr.) Keissl. belongs to fungi that live as saprophytes on many kinds of plants. They lower the rate of photosynthesis, reducing the access of light to tissues and interfering with gas exchange [7]. Under conditions of excessive moisture the fungus can move from saprophytic form to parasitic. High humidity (over 96\%) and periodic changes of dry weather with rainy one at temperatures not below $22^{\circ} \mathrm{C}$ contribute to its development [3]. A. alternata is a secondary pathogen on beets that penetrates mainly into chlorotic beet leaf areas, particularly affected by weak chlorosis virus and debilitated by the lack of macro- and microelements [8;9]. In addition, it is believed that the pathogen is a complex of species, so-called "pathotype" of many fungi of Alternaria genus, but the issue today is uncertain and requires additional studies [10; $11]$.

Besides the harmfulness to crops, scientific literature marked mutagenic effect of $A$. alternata culture liquid, isolated from corn in China, in the region with a high level of human esophageal cancer, on bacteria and human cells [10].

Due to prolonged use of the same fungicide the increase of resistance is observed in the pathogen. Thus, in the USA the percentage of Cercospora beticola spores resistant to benzimidazole derivatives was higher in areas where the preparation was most often used. Such pathogen resistance was caused by $\alpha$-tubulin and $\beta$-tubulin genes mutation under the influence of benzimidazole. The isolates of that mutation have an increased sensitivity to phenylcarbamate $[12 ; 13]$. In Hungary, the resistance of Alternaria species to benomyl was found, which greatly accelerated the drying of beet leaves [14].

High degree of variability in cercospora isolates promotes the increasing of resistance to fungicides. Thus, in Greece among 45 isolates from four beet-growing areas 45 pathogen genotypes of cercosporosis were identified, which differ with variability, preferably, within a population [15].

Rapid development of cercospora strains tolerant to fungicides, is explained by high adaptive capacity of the fungi of that genus [16]. In addition, it was studies that low application rate of some fungicides, especially Kuproksil, Benlat and Topsin act as mutagens to $C$. beticola conidia, and single mutants have much higher virulence compared to the isolates of fungus natural type [17]. 
Due to the urgency of the issue and conflicting data on the effectiveness of fungicides we studied the impact of fungicides solutions on the germination of conidia of fungi-pathogens of cercosporosis and Alternaria spot disease of sugar beets depending on the duration of storage and the origin of the isolates.

Materials and methods. For comparative evaluation of sustainability of Cercospora beticola Sacc. and Alternaria alternata (Fr.) Keissl. conidia to storage and influence of fungicides studied was the effect of $0.1 \%$ and $0.01 \%$ solution (by active substance) of fungicides on the germination of conidia obtained from leaves affected by spot disease that were stored for 6 months in dry state and from stains on the living leaves.

Laboratory studies fungitoxicity of preparations were carried by the method of germination of spores on glass slides [18].

The suspension of fungi spores was prepared by washing conidia out from beet leaves after the exposure in a humidified chamber for amplifying the sporification. Required preparation concentrations $(0.1 \%$ and $0.01 \%$ ) were received by $20-200$ times dilution of $2 \%$ stock solution (by active substance) with distilled water.

The identification of isolated fungi was carried out by cultural-morphological characteristics [19].

The percentage of inhibition of $C$. beticola fungus conidia germination was calculated by Abbott formula [18]:

$$
\mathrm{T}=\frac{(\text { ПК-По) } \times 100}{\Pi \kappa},
$$

where $\mathrm{T}-$ percentage of spores germination inhibition, \%;

Пк - percentage of germinated sporesin control, \%;

Пo - percentage of germinated spores in preparation solution, $\%$.

Concentration equalization by active substance was carried out according to the equation:

\footnotetext{
Concentration of preapration $(\%)=$ $=\frac{100 \times \text { concentration by active substance }}{\text { content of active substance in preparation (\%) }}$
}

In vitro was performed the determination of braking action of fungicides solutions: Impact 25, SC, concentrate of suspension, (25\% flutriaphol) -0.25 1/ha, Rex Top, concentrate of suspension, (25\% phenpropimorph $+8.4 \%$ epoxiconazole) -0.8 1/ha, Alto Super 330 EC, concentrate of emulsion, ( $8 \%$ cyproconazole $8 \%+25 \%$ propiconazole) - $0.41 /$ ha Derozal concentrate of suspension, (50\% carbendazim) $-0.5 \mathrm{l} / \mathrm{ha}$ and Subtan, liquid paste, (analogue - Agat25K, inactivated bacteria Pseudomonas aureofaciens $2 \%$ and products of their metabolism 38\%) - 0.15 1/ha on germination of pathogens conidia of cercosporosis and Alternaria spot disease of sugar beets. Hectare preparation standard contains Impact $25 \mathrm{SC}-$ $62.5 \mathrm{~g}$ of active ingredient, Subtan $-60 \mathrm{~g}$, Alto Super - 165 g, Derozal - 200 g and Rex Top - $233.8 \mathrm{~g}$ of active ingredient, the concentration of working solutions is corresponding. Braking action of these preparations on the germination of spot disease pathogens spores at equal concentration by active substance was determined.

So, $C$. beticola fungus conidia are less resistant to fungicides than A. Alternate spores, which indicates possible problems in controlling Alternaria spot disease of sugar beets in the future.

The effectiveness of inhibition of cercosporosis pathogen conidia germination by fungicides is reduced under processing of spores from vegetative plants, compared with previous year's models.

Effective against the germination of spores of cercosporosis fungus-pathogen are fungicides Derozal and Alto Super, against Alternaria spot disease of sugar - Alto Super. Least of all the germination of conidia of both pathogens was inhibited by biofungicide Subtan. Although fungi hyphae were practically not viable in fungicide solutions, the chance for appearance of resistant to certain preparations isolates of $C$. beticola Sacc. and A. alternata (Fr.) Keissl., especially at low concentrations of fungicides, is quite high.

The isolates of $C$. beticola and $A$. alternata from Khmelnytskyi SAES and isolates from Ivanivka ESS exhibit varying resistance to fungicides activity. These data should be considered in further studies of the biology of these pathogens and in the practice of fungicides application against them. 